InOedia $\quad \begin{aligned} & \text { InMedia } \\ & \text { The French Journal of Media Studies }\end{aligned}$

7.1. $\mid 2018$

Visualizing Consumer Culture

\title{
Wine labels and consumer culture in the United
} States

\section{Eléonore Obis}

\section{(2) OpenEdition \\ 1 Journals}

\section{Electronic version}

URL: http://journals.openedition.org/inmedia/1029

ISSN: 2259-4728

\section{Publisher}

Center for Research on the English-Speaking World (CREW)

\section{Electronic reference}

Eléonore Obis, « Wine labels and consumer culture in the United States », InMedia [Online], 7.1. | 2018, Online since 20 December 2018, connection on 08 September 2020. URL : http:// journals.openedition.org/inmedia/1029

\footnotetext{
This text was automatically generated on 8 September 2020.

(c) InMedia
} 


\title{
Wine labels and consumer culture in the United States
}

\author{
Eléonore Obis
}

\section{Introduction}

\section{Preliminary remarks}

1 The wine market is a rich object of study when dealing with the commodification of visual culture. Today, it has to deal with a number of issues to promote wine, especially market segmentation, health regulations and brand image. First, it is important to find the right market segment as wine can be a luxury, collectible product that people want to invest in. ${ }^{1}$ At the other end of the spectrum, it can be affordable and designed for everyday consumption (table wine). The current trend is towards democratization and convergence in the New World, as wine and spirits consumption is increasing in countries that traditionally drink beer. ${ }^{2}$ Second, the market has to reconcile pleasure with health legislations imposed by governments and respect the health regulations of the country. The wine label is the epitome of this tension between what regulations impose and what the winemaker intends to say about the wine in order to sell it. Third, brands and wineries must build a positive brand image. Some of them favor for instance an environmentally friendly approach, which is consistent with some of the customers' expectations. This is particularly true for millennials in the US who tend to favor sustainability. ${ }^{3}$ Although the organic market is still a niche in the US ( $1 \%$ of wine sold in volume in 2016) compared to Europe, there are signs of growth in the sector ${ }^{4}-$ driven by competition with European organic wines.

2 Strategies to sell wine have dramatically changed since the US started developing as a wine producing country. The main factors are globalization, ${ }^{5}$ and along with it, the development of online sales ${ }^{6}$ and the growing importance of social media. ${ }^{7}$ In this new market, one cannot but see the increasing role of wine labels in marketing, and their transformation to target a specific audience. Labels have always been essential to sell wine and are paramount in the story and identity of most historic wineries. Mouton- 
Rothschild in Bordeaux is a case in point in wine marketing history, as I demonstrate below. Analyzing wine labels highlights some major trends in the market.

\section{Labels and marketing}

3 The offer in wine is so diverse that it is proving increasingly difficult for the consumer to buy the right wine for the right occasion. The 2016 American Wine Consumer Survey shows that most wine in the US is purchased in wine/liquor stores, then in grocery stores, and finally in discount/warehouse stores, such as Target or Costco. ${ }^{8}$ When comparing with other products, most supermarket categories usually have about 10 brands while wine has over $700 .{ }^{9}$ More and more wines carry brand names that have a major influence on the purchase-brands dominate in the New World, contrary to the Old World, and account for more than half of the wine sales in the US. ${ }^{10}$ This is where label design comes into play and contributes significantly to the success of one brand compared to another in the retail wine trade.

4 Brand is only one of the multiple cues that influence purchase. They can be divided into intrinsic and extrinsic cues, which are attributes commonly used in marketing research and developed by Jerry Olson and Jacob Jacoby in $1972 .{ }^{11}$ Intrinsic cues are linked to the intrinsic characteristics of the product, such as the grape varietal, the alcohol content, the processing method, or style of the wine. Extrinsic cues can be changed without changing the product: price, packaging (label), and brand name. Research has shown that consumers base their choice on a combination of those factors, and the 2016 survey confirms that price and brand names are key for consumers-respectively $80 \%$ and $66 \%$ of respondents chose them as the most important factors-followed by varietal $(46 \%)$, country (35\%) and label (18\%). One conclusion is that consumer choice for wine is more complex than the choice for any other product. According to Larry Lockshin, "it might be argued that automobiles are one of the few product categories that rival the complexity of the wine category." ${ }^{12}$

5 As a consequence, the choice of wine cannot be based on informed choice only, and the visual aspect of a bottle matters immensely in the final decision. The visual language of a label is as important as the information displayed on it: although the 2016 survey puts this factor in fifth place, the label defines the brand's image and makes all the information on country, varietal, or winery visible to the consumer. The shape, color, and information it displays make the product recognizable and readable by consumers. ${ }^{13}$ Many studies confirm the influence of labels in buying wine. In a 2010 study, German wine consumers first tried wines in blind conditions, and then tried the same wines with the packaging information. The result was that "overall, label style and brand evaluation were the strongest drivers for informed liking followed by liking in the blind condition." ${ }^{14}$ In another study on US consumers led by Claire A. Boudreaux and Stephen E. Palmer ${ }^{15}$ the color and layout were also considered and were shown to influence consumer choices.

\section{The US wine market}

6 Consumption of wine in the US has been steadily increasing since the 1980s, as it went from 480 million gallons in 1980 to 949 million in 2016. Contrary to common perception, the US has been the world's largest wine market since 2010, and it is the 
number one country for wine consumption, France and Italy ranking respectively second and third. As for the US wine production, it ranks fourth after France, Italy, and Spain, and is mainly concentrated in California, which accounts for $85 \%$ of the total US wine production. ${ }^{16}$

7 This general growth in production and consumption reflects a change in the US consumer base: millennials-also called "Generation Y", born between 1980 and 2000are reaching legal drinking age and now make up about a third of consumers over 21 years old. Thus, wineries need to tailor their wines and adapt their marketing to appeal to this group. The other important market segments are Generation X-born between 1965 and 1980-and Baby Boomer consumers-born between 1945 and 1965-who are considered more experienced wine drinkers. ${ }^{17}$ According to Humphrey Serjeantson, a senior analyst at the International Wine \& Spirit Research (IWSR), a London-based drinks research group,

The US is the biggest market in the world for wine and will remain the biggest market up to 2018 by quite a margin. What we are seeing in the US is that it is increasingly common for millennial consumers to drink wine with meals. But there is no doubt consumers in the U.S. are becoming more knowledgeable and educated about wine. ${ }^{18}$

8 A 2016 Wine Opinions survey, called "American Wine Generations," concludes that millennials tend to focus on wines that are inexpensive (around \$10). They are more adventurous in terms of regions and countries as they like trying new wines; unsurprisingly, they are also more connected, and will buy wine using all the information they can get on social media. ${ }^{19}$ According to other studies focusing on California consumers,

Gen $Y$ consumers preferred cheaper wines to the other generations (...) Baby Boomers and Gen X consumers thought more highly of old World wine producing regions and focused more on brand name and quality than Gen Y (...) Young consumers tend to drink wine more for pleasure than to appreciate differences between styles and regions. ${ }^{20}$

9 American brands and wineries have had to change their marketing strategies in order to adapt to this evolution in the consumer base. Today, more than 160,000 wine labels are approved for sale annually by the Tobacco Tax and Trade Bureau in the US. ${ }^{21}$ Finding the right label to be visible on the market is thus a major stake. Wine is a unique product, at the crossroads between nature and culture, first through its transformation from grape to wine, and then through bottling and labeling, processes which turn wine into a cultural product. ${ }^{22}$

10 My contention is that the current trends in label designs in the US are oscillating between culture and nature, revealing the duality of wine itself. On the one hand, labels are using US popular cultures, tapping into the consumer's lifestyle and culture, commodifying them and often erasing all traces of traditional wine culture. On the other hand, wine label design follows a global trend towards the promotion of a more "natural" product-with the development of more "sustainable" wines. This "back to nature" marketing strategy does not target the same customers and puts forward the intrinsic qualities of the wine and the role of terroir. 


\section{The visual culture of wine}

What is a label? How does it work? First, there is not one label, there are two: the front label and the back label. Second, US labels have specific legislative requirements that are different from the European ones. As it is difficult to tell the difference between the front and back labels on a round bottle, the front label is usually the one that is there to sell the wine visually, the label that catches the user's attention, while the back label provides all the legal information. The back label often includes elements about the winery's history, a taste description of the wine, and food pairing examples. ${ }^{23}$ In the US, the label must include a geographical reference-such as country, state, and American Viticultural Area (AVA $)^{24}$-a brand name, a vintage date when there is an appellation of origin- $85 \%$ of the grapes must then come from that place, it can be a country, state, or county-the varietal designation when there is an appellation of origin-the wine must then contain $75 \%$ of the grape variety-the name and address of producer or bottler, the alcohol content, the volume of wine, and the declaration of sulphites. A health warning statement is also required by law: it includes a warning for pregnant women and people in charge of heavy machinery. ${ }^{25}$

Wine producers have always been aware of the essential role of labels in marketing, be it in Europe or the United States. For instance, they have used visual arts on their labels, in order to distinguish themselves. Traditionally, however, visual arts on labels, whether paintings, drawings or cartoons by artists or graphic designers, have belonged to upscale wine in the old World, namely the wineries which could afford to pay an artist to create a unique label for them. The pioneer in this field is the Bordeaux area, with the famous example of Mouton-Rothschild, which in 1924 started to ask an artist to create the label for each vintage of its wine. The chateau has a room displaying the original paintings of the labels, with artworks by Francis Bacon, Jeff Koons, Anish Kapour, Andy Warhol, Salvador Dali to name but a few. The labels show the interesting confrontation between the classicism of the label and the proposition of the artist. ${ }^{26}$ The message is that the wine combines tradition and modernity: a certain classicism, with the stable and recognizable qualities of an upscale wine, and the contemporary world in its finest through art. The marketing concept is clever in that it pairs wine with art, and promotes wine making to an art and winemakers to artists. Besides, the label adds value to each vintage as each bottle becomes a collectible. Steve Charters suggests that wine labels have therefore become a work of art and "the artistic label acts as metaphor for the wine; the consumer may be unable to appreciate the aesthetic qualities of the drink, at least until the cork is pulled, but the label signifies what its aesthetic value will ultimately be." ${ }^{27}$ The concept was taken up by the most famous wineries in the US, from Robert Mondavi to Kenwood Vineyards in Sonoma County or Hargrave Vineyards on Long Island. ${ }^{28}$ Thanks to this marketing strategy, each winery can build a distinct brand image and identity while strengthening their position in the upscale wine market.

The phenomenon of developing visual arts on wine labels is amplifying. There are now companies that specialize in wine label designs and wine marketing, so the process has become mainstream. In the US, the development of label design partakes of the need to create a history and culture for wine that would be completely American, neither turned towards the past nor influenced by Europe and its traditions. Although the first settlers were really intent on trying to make wine as early as the $17^{\text {th }}$ century, it was 
only around 1806 that the first successful American wine production began, in Indiana. ${ }^{29}$ Today, the labels of the New World are usually considered to be bolder than the ones in Europe, or at least less classic: such a need to create a past and a cultural history of wine is illustrated in the recent exhibition at the Modern Art Museum in San Francisco in 2010-2011 called "How Wine Became Modern' Design + Wine." It explored the visual culture of wine and its transformation over the last three decades. This exhibition combined historical artifacts, architectural models, design objects, and installations, including a "smell wall" and a label wall to explore the new strategies in label design. Henry Urbach, the museum's architecture and design curator explained: "The show is really about representation. Wine became modern as it became concerned with representing itself as culture. Think about it: No other comestible has produced a visual culture like this." ${ }^{30}$ And indeed, the exhibition demonstrates that wine has become part of American culture and American culture has been integrated into wine culture.

The labels on display were grouped according to different themes-among which, to quote but a few, "good guys", "bad guys", "femme", "cheeky", "sex", "fame"-and it appears clearly that

in order to attract attention to their brands on retail shelves wine producers are creating flashy, eye-catching packages, that yell 'Buy me.' Sometimes these packages have questionable connection to the wine, and some are even in bad taste. (...) These labels strive to distinguish themselves from stuffy old World and old Boy wine traditions." ${ }^{31}$

15 A major characteristic is then to differentiate the US wine identity from that of the European one. Liz Thach, professor of wine marketing at Sonoma State University, explains that these labels were more attractive to millennials: "Millennials are turned off by the labels with a picture of a chateau on them. They think that's their grandfather's wine." ${ }^{32}$ This evolution of wine labels partakes of the democratization of the wine market in the US and shows how they have become part of the US culture, through a specific process that tends to steer away from traditional wine culture and European labels, in order to catch up with the new generations and consumers.

\section{Popular cultures against wine culture}

Conversely, popular culture has become part of wine labels, as wine is a way for consumers to express their identity and lifestyle. Theories of consumer culture, including those of Jean Baudrillard or Fredric Jameson, link this combination of different cultures to a postmodern consumer culture through the analysis of signs. In Postmodernism, or, the Cultural Logic of Late Capitalism, Jameson describes our postmodern society as one where '“culture' has become a product in its own right (...) Postmodernism is the consumption of sheer commodification as a process". ${ }^{33}$ One of the main characteristics of this postmodernism is "the effacement of the older (essentially high-modernist) frontier between high culture and so-called mass or commercial culture". ${ }^{34}$ Mike Featherstone synthesizes Jameson's theories, underlining how this culture is characterized by a "saturation of signs and messages to the extent that 'everything in social life can be said to have become cultural'. This 'liquefaction of signs and images' is also held to entail an effacement of the distinction between high and mass culture." ${ }^{35}$ The "liquefaction of signs and images" contributes to the blurring of the frontiers between different cultures and approaches to wine, where the high culture of art or wine connoisseurs is seized upon in order to become part and parcel of 
popular culture. In the field of wine labels, it means that a label today can have nothing to do with the wine.

In his sociological approach to lifestyle and consumption, Alan Tomlison analyzes the evolution of these trends. Firstly, he argues that "lifestyle as a motivational factor is diminishing the relationship between social class and status. Status may still be important, but it is no longer about establishing one's class and much more about affirming one's individuality." ${ }^{36}$ Wine is the perfect product to reassess the individual choice of consumers: choosing a bottle with the label that suits him/her most, the consumer can find a way to express his/her identity. Secondly, "technical and production factors will become less significant than lifestyle-related issues. This means that the focus will shift from the way that wine is produced (including, perhaps, issues such as terroir) towards the specific experiential needs of the consumer." ${ }^{37}$ These shifts towards lifestyle, individuality and experience in consumer culture can be observed on wine labels today. One trend is to associate wine with another passion, be it music, cinema, or sports to name a few. Wine is there to reflect one's lifestyle, good taste and identity, and these labels usually tend to stress the experience of wine drinking as easy and trendy: it does not associate wine with painting (like upscale wines) but with hobbies that are popular and more accessible, and hence also targets different types of consumers, that is, not the connoisseurs, but aspirational, average or new drinkers. ${ }^{38}$

For instance, the US network Turner Classic movies has a wine club for its subscribers. ${ }^{39}$ The point of belonging to this wine club is to get special offers and prices on wines. In this case, the wine and its quality are definitely not the main concern of the consumers -the main point is to attract the consumer through the choice of the movie, thanks to the label. The slogan is "Uncork the fun of movies and wine" associating the wine drinking experience with watching a movie, "the fun of movies" being mentioned first. Interestingly, this wine club was created in partnership with the Francis Ford Coppola winery, in Napa Valley, which is like a "wine amusement park" that can be visited. Just like its owner, the famous director, the location itself already blurs the frontiers between the worlds of cinema and wine. Wine, like movies, is considered as entertainment. Some examples of the wines on offer include Francis Coppola Director's Frankenstein Cabernet Sauvignon 2014 (with a picture of Frankenstein on it), Orson Welles Signature Selection Merlot 2013 (with a black and white picture of Orson Welles), Alfred Hitchcock Presents Zinfandel 2014 (with a picture taken from the movie Vertigo). Interestingly, the movies chosen are classics, so that they are completely in tune with the contents and identity of the channel. Looking at the years when those movies were released-Orson Welles movies, from Citizen Kane, 1941 to The Trial, 1962; Alfred Hitchcock Presents, 1955; Vertigo, 1958; Coppola's Frankenstein, 1994-it appears clearly that the wine club is targeting mostly baby boomers and Generation $\mathrm{X}$ customers. This emphasis on the visual aspect of the label leaves behind all the important information concerning the wine itself-such as grape, year, or region-and one can legitimately wonder what criteria were chosen to match a specific wine with a specific movie, as the link between Cabernet Sauvignon and Frankenstein remains unclear for instance. Buying and drinking these wines allow for a sense of individuality as these wines are designed to distinguish themselves from wines that are "mass produced"40 thanks to the label and the marketing concept of the "wine club." Yet, there is a paradox here, as the movies chosen are world famous, mainstream and belong, then, as much to the "masses" as Francis Ford Coppola's wines. The process of 
cultural commodification, along with the breakdown of the distinction between what we could call "high" and "low" culture transforms these wines into products for the masses, even though the masses chose to be part of a wine club.

Another recurring example of wine pairing is rock and roll. It is of high interest as this music was born in the US, is strongly rooted in the US culture and can be considered as a symbol of the American way of life. ${ }^{41}$ It also has the potential to appeal to different generations of customers.

A first case is that of the Las Vegas-based company called Rocknroll Wine. ${ }^{42}$ Founded in 2003 by Chris Hammond and Sonny Barton, the concept is to "make wine less pretentious through music to attract millennial drinkers. Over the past ten years, the company has produced over 200 events in 5 states including ten Reggae Festivals and eight of their signature Wine Amplified Festivals." ${ }^{43}$ On the website, each bottle is defined by a series of adjectives answering the question "which bottle fits your mood": "playful", "mischievous", or "naughty" to name but a few. The adjectives themselves could be applied to both customer and wine. The stress is on the "cool" aspect of the experience-there is no precise information on the wine itself. The brand label shows a guitar player jumping, an image reminding of a rock concert and underlining the idea of rock as entertainment. The player is also holding an open wine bottle and the slogan - "rock out with your cork out"-echoes the innuendoes found on the labels. Regarding prices, which range from $\$ 15.99$ to $\$ 20.99$, the wines are expensive enough to make the customers believe the wine is better than average, but unmistakably too low for it to be excellent wine on the US market. The labels display the logo of the company with the name of the wine-Rhapsody, Mo'se and Grotto. It is worth noting that the "rock and roll" connotation of those terms is questionable and could mislead customers: apart from the term "Rhapsody", which seems to echo the title of Queen's song "Bohemian Rhapsody", the other terms do not appear as clear references to rock and roll. Moreover, as with the movie-themed bottles, the quality of the wine and its characteristics are definitely not what matters. The wine drinking experience is presented as an entertainment that is affordable and enticing and not the preserve of experts-to the point that even the grapes or the region do not feature on the labels. The festive experience, which is that of a rock concert or party with friends-where wine is present more as alcohol with a disinhibition effect than as a cultural productand the sense of individuality are what matters.

21 The second example is a company called Wines that rock, which offers an interesting parallel in terms of visual label impact. ${ }^{44}$ The managers present themselves as "passionate wine lovers and die-hard music fans" offering "Great Tasting Wines Inspired by Music," "with classic tracks from Grateful Dead, The Rolling Stones, Pink Floyd, The Police, and The Woodstock Festival." ${ }^{45}$ What attracts the customer to the wine label is the name of the band, or the familiar album cover or the use of the famous bands' visuals and logos: the red mouth with tongue sticking out for the Rolling Stones, the cover of the album Synchronicity for The Police, or the drawing of a bird for Woodstock to name but a few. They were all chosen because they are classics, and as such, are likely to appeal to a large audience: these bands sold millions of albums, through three generations-baby boomers, generation $\mathrm{X}$, and to a lesser extent perhaps, generation $\mathrm{Y}$. The presentation of the company highlights the rupture with classic wine marketing:

Wines That Rock is approaching the wine business in a totally new way. This is not your Grandfather's Wine Company (...) Wines That Rock is out to change the boring 
perceptions of your typical wine. Wines That Rock is meant to be fun, a conversation starter, an eye-popping party gift. ${ }^{46}$ beer drinkers-accept wine as part of its culture. This is done mainly through the labels: "Our back labels are set up just like the back of the album jacket, liner notes and all. Wines That Rock is not your typical wine experience and these are not your typical wine labels. These are tapestries from the rock vaults. Classic, iconic album art that's part of YOUR musical DNA." ${ }^{\text {47 }}$ The bottles are part of rock history, which makes for a particular experience, and makes the bottle special, not destined to the "masses." In this case again, the stress is put on what wine says about the consumer-their personality, the music they like-their lifestyle, and not on the wine itself. On the webpage, the description of the taste of the wines is placed first to define the products, but with the vague formulation "great tasting wines". The company does not really develop more about the grapes, or winemaking. Then, this brand addresses millennials who do not have the financial means of baby boomers, and the wines reflect their culture and identity but considering the bands chosen, it might as well work for the other generations. Belonging to a "clan" or "club" of people that can gather in a festive way around a bottle of wine to celebrate rock and roll is the main incentive to buy this wine. Wine is entertainment: it is not there to be analyzed and is not reserved to wine connoisseurs.

\section{Back to nature}

There are many different marketing strategies in labeling, and it is unfortunately not possible to address all of them here. One that is particularly relevant to this study is completely different from the commodification of popular cultures strategies and focuses on wine as a natural product. I called that trend "back to nature" and it is not only developing in the US but on a global scale. First, wine makers and wine brands are more and more concerned with the environment, for ethical and/or marketing reasons. Wineries can get an organic certification as well as a biodynamic certification (through the Demeter certificate) but these are usually quite expensive or imply various constraints, so it is easier to put forward sustainability or a low environmental impact on the label. There are specific labels in the US. For instance, Oregon has a regional eco label called Salmon safe, which started in farms in 2007 and then spread to vineyards. Salmon-Safe helps vineyards protect and restore salmon habitat, while also applying natural methods to control weeds and pests. ${ }^{48}$ This kind of label contributes to give products a greener image.

Wine brands, like other brands, can use green washing as a marketing device. More and more brands feel the need to build a green image in order to create a more positive story for their product. They do not need certifications and can just be vague or even lie about their green credentials..$^{49}$ For instance, winemakers or brands can print on the labels that they are concerned about the environment; that they work in the respect of nature; or that their wines are made with healthy grapes. It does not require them to have a label or certification, and it could mislead the customers as to their viticultural practices: a "concern", or "respect" for the environment does not mean pesticides or fertilizers are not used. The front and back labels are main factors of reassurance for 
the consumer in quest of a certain quality and authenticity when it comes to buying wine. According to Michael B. Beverland, who led a study on luxury wines:

Authenticity can be defined as a story that balances industrial (production, distribution and marketing) and rhetorical attributes to project sincerity through the avowal of commitments to traditions (including production methods, product styling, firm values, and/or location), passion for craft and production excellence, and the public disavowal of the role of modern industrial attributes and commercial motivations. ${ }^{50}$

In order to fit with some customers' quest for authenticity, designers have come up with three main images: the vine (and grapes), the roots, and the tree. ${ }^{52}$ I now analyze how they combine the three main authenticity factors into one image. First, these labels show wineries have a tradition and a history: the image of the vine with the roots point to one place, one location, the work of the soil, and the attachment to the terroir. The question of terroir is fundamental when dealing with old World wines and New World Wines. The terroir is "a much-discussed term for the total natural environment of any viticultural site." ${ }^{53}$ While European Wines tend to push this specificity very farthere are numerous terroirs, especially in France, which all have their own characteristics, from soil to climate, viticulture and so on-New World Wines have been "discovering" terroir in the last 20 years, or at least, because the US wine regions are quite young, they are trying to find their own terroirs. Jancis Robinson underlines this shift in the New World:

The New World approach to vineyard design is now much more likely to take soil differences into account. New World vineyards were once most likely to have been subdivided according to existing boundaries, shape, topography or whim. Today it is increasingly common to allow a soil survey and soil mapping to determine choice of variety, rootstock, treillis system..$^{54}$

As the concept of terroir is slowly gaining ground in the wineries, a brand image linked to the soil on labels is starting to take root and to spread. The wine must be perceived as unique in its terroir and history.

These labels are usually not flashy or bold, they are rather minimalistic and show what is essential: the vine from which the wine is produced. In this sense, they mark a return to a certain classicism, not to say conservatism. They are usually in black and white; sometimes some red or yellow can appear (for red and white wines respectively). The vines shown are usually old vines, which look like small trees. For the connoisseur, they are also the sign of less productivity but better, more concentrated grapes: they embody the perfect combination of authenticity and high quality. 
Second, these images suggest respect for the earth and terroir through the link with a rural environment. The vines are often shown in a field, sometimes with leaves and grapes (in summer), or without (in winter). There are no signs of human presence, and nature seems to take the whole stage: again, the wine is made unique through its origin, and human intervention is presented as minimal. The winemaker is only there to get the best out of the grapes; wine is presented as a "natural" product. No machines, tubes, or stainless steel tanks are shown.

What is more, the image of the vine with its roots recalls the image of a tree. It is connoted very positively and associated with the protection of the environment on many logos for different commodities, another strong point in this marketing strategy. The US main organic brand, Bonterra, is a case in point: their organic collection has a label that combines a classic display of the main info in black and white, with the branch of a tree in the right-hand corner. In order to distinguish the different wines, a different colored bird or insect is perching on one of the branches. Their biodynamic collection, which has three single-vineyard wines, is also classic in terms of label, in black and white, except for the colored painting of a tree for their flagship wine called "The Butler". ${ }^{55}$

This trend, through its display of environmental awareness and its stress on traditions and roots, may reconcile all the different customers around the world: it is attractive to the younger customers, who may be concerned with the environment, but also to older and more informed customers, who will identify with the classic display of these labels. The 2016 American Wine Consumer Survey confirms the trend could work. When presented with three different labels (traditional, modern and funny), "survey takers were asked 'Which of the following wine label styles appeals to you the most?' Supporting prior research, $64 \%$ of American wine consumers favored the traditionally design label, $23 \%$ the modern style label, and only $13 \%$ the fun and whimsical label." It is worth noting that the traditional label represented a "chateau" in black and whitemore reminiscent of Napa Valley's architectural style than Bordeaux's.

The irony in this is that the multiplication of these labels makes them look the same all over the world, hence questioning the sincerity of the wineries and the authenticity of their stories. Some of these labels, with their sober, classic and minimalist design can remind us of the old and New World's labels of the nineteenth and first half of the twentieth century-some of which displayed drawings of vines with grapes, some in black and white and just the essential information about the wine (name, appellation, or village). ${ }^{56}$ Labels started to spread in the nineteenth century, thanks to the development of bottles and the invention of lithography. Two centuries later, a return to more minimalist labels cannot but remind us of these first labels: incidentally, the latest top trends put forward by a marketing agency were "go classic, simple and handmade." ${ }^{57}$ Could wine marketing be going back to the nineteenth century's marketing strategies?

Label design is a complex marketing field. Wineries and wine brands are required to research thoroughly their target consumers in order to make sure the wine will sell in the retail wine trade. To meet customer's expectations, the label must suggest that the wine is in touch with a certain sense of tradition (a term that has to be qualified, especially in the US market as it is not as ancient as the European one) and at the same time breaks away from the classic, serious Bordeaux-style wine labels-the world reference in the field-in order to appeal to all consumers. Nowadays, labels recycle all 
sorts of visual elements drawn from popular culture, music, movies, or series in order to broaden the client base, but also to allow each winery to stand out and build a distinguishable visual identity. In contrast, a "back to nature" marketing strategy seems to take over the US and the global market, marking visually a focus on what makes the wine: vine and terroir. It remains to be seen whether this latter trend is a sign of real evolution for brands and wineries as far environmentally friendly practices and sustainability are concerned.

\section{BIBLIOGRAPHY}

Beverland, Michael B. "Crafting Brand Authenticity: the Case of Luxury Wines.” Journal of Management Studies 42:5 (July 2005): 1003-1029.

Bonterra website http://www.bonterra.com/ <accessed March 1, 2018>

Boudreaux, Claire A. and S. Palmer. "A charming little cabernet: effects of wine label design on purchase intent and brand personality." International Journal of Wine business Research 19 (2007): 170-186.

Caldewey, Jeffrey. Icon: Art of the Wine Label. Wine Appreciation Guild Limited, 2003.

Charters, Steve. Wine and Society. Oxford: Elsevier, 2006.

Cobbold, David and Sébastien Durand-Viel. Le vin par l'étiquette. Paris : Hachette Pratique, 2013. Colin, Michael Hall and Richard Mitchell. Wine Marketing: A Practical Guide. Oxford: Elsevisier, 2008.

Featherstone, Mike. Consumer Culture and Postmodernism. London: Sage, 1991.

Franson, Paul. “Labels Gone Wild,” Wine Enthusiast, 1 March 2016.

Hoestra, Inkje, Conrad Lashley and Elena Cavagnaro. "Generation Y's Attitude Towards Organic Wine.” Research in Hospitality Management 5 (1), (2015): 107-113.

Jameson, Fredric. Postmodernism, or, the Cultural Logic of Late Capitalism. Durham : Duke UP, 1991. Jeanneret, Yves and Emmanuël Souchier. "L'étiquette des vins : analyse d'un objet ordinaire." Communication et langages $\mathrm{n}^{\circ} 121$, (1999): 72-85.

Jennings D. and C. Wood. "Wine: Achieving competitive advantage through design." International Journal of Wine Marketing vol. 6 (1), (1994): 49-61.

Lockshin, Larry and Armando Corsi. "Consumer behaviour for wine 2.0: A review since 2003 and future directions." Wine Economics and Policy 1:1, (December 2012): 2-23.

Lockshin, Larry and John Hall. "Consumer purchasing behaviour for wine: what we know and where we are going." University of South Australia, Wine Marketing Research Group (2003).

Loosdec, Ted. "Lots of Wine, but None to Drink," New York Times, (05 December 2010).

Lyons, Will. “Who's driving world wine consumption?” Wall Street Journal online, (28 January 2015). 
Margot, Philippe. L'Art et le Vin : Les œuvres originales de grands artistes contemporains pour Château Mouton Rothschild. Editions Cepdivin, 2009.

Morgan, Gareth and Richard Tresidder. Contemporary Wine Studies. Dancing with Bacchus. New York: Routledge, 2016.

Mueller, Simone and Larry Lockshin et al. "Message on a bottle: the relative influence of wine back label information on wine choice," Food Quality and Preference 21, (2010): 22-32.

Mueller, Simone and G. Szolnoki. "The relative influence of packaging, labelling, branding and sensory attributes on liking and purchase intent: Consumers differ in their responsiveness." Food Quality and Preference 21, (2010): 774-783.

Nielsen, “Green Generation: Millennials say sustainability is a shopping priority," http:// www.nielsen.com/us/en/insights/news/2015/green-generation-millennials-say-sustainabilityis-a-shopping-priority.html <accessed on May 26, 2018>

Olson, Jerry C. and Jacob Jacoby. "Cue Utilization in the Quality Perception Process," SV Proceedings of the Third Annual Conference of the Association for Consumer Research, eds. M. Venkatesan (1972): 167-179.

Pinney, Thomas. A History of Wine in America: From the Beginnings to Prohibition. Berkeley: University of California Press, 1989. http://ark.cdlib.org/ark:/13030/ft967nb63q/ <accessed on May 26, 2018>

Robinson, Jancis. The Oxford Companion to Wine. Third Edition, Oxford: Oxford University Press, 2006.

Rocknroll Wine. http://www.rocknrollwine.com <accessed March 1 2018>

Salmonsafe. https://salmonsafe.org/ <accessed March 1 2018>

Sherman, Scott and Tracy Tuten. "Message on a bottle: The wine label's influence." International Journal of Wine Business Research vol. 23 Issue 3 (August 2011): 221-234.

Strayer, Pam. "The Organic Opportunity: will the US wine industry miss out," Wines and Vines, (January 2017), https://www.winesandvines.com/columns/section/26/article/178258/TheOrganic-Opportunity-Will-the-U.S.-Wine-Industry-Miss-Out <accessed on May 26, 2018>

Thach, Liz and Kathryn Chang, "Adventure, Tradition, and Semi-Sweet Wines Highlighted in 2016 American Wine Consumer Survey," 6 December 2016, Wine Business.com https://www.winebusiness.com/news/?go=getArticle\&dataid=177492 <accessed March 1 2018> Tomlinson, Alan (Ed.). Consumption, Identity and Style. London: Routledge, 1990.

Turner Classic movies wine club. http://tcmwineclub.com/ <accessed March 1 2018>

“Wine Opinions. American Wine Generations report,” Wine Business Blog, 24 March 2016

https://www.winebusiness.com/blog/?go=getBlogEntry\&dataId=166661 <accessed March 1 2018>

Wine Institute. https://www.wineinstitute.org/ <accessed March 1 2018>

Wines that rock. http://www.winesthatrock.com <accessed March 1 2018>

\section{ENDNOTES}

1. Some wines are collectible only because of their labels. People who collect them are called vintitulists. 
2. Steve Charters, Wine and Society (Oxford: Elsevier, 2006), 200.

3. See the result of a 2015 Nielsen Global Survey. "Green Generation: Millennials say sustainability is a shopping priority."www.nielsen.com/us/en/insights/news/2015/greengeneration-millennials-say-sustainability-is-a-shopping-priority.html <accessed on May 26, 2018>

4. "In the off-premise channel in 2016, case volume grew $10 \%$ for organic wines-nearly five times the average volume growth. On the revenue side, organic wines rose $12 \%$-roughly double the average of all wine." "Supermarket wines that are organic are doing well-very well: Bonterra, America's largest organic wine brand (approaching 500,000 cases), had its best year ever in 2016 (...) The brand, which makes only 'Made with Organic Grapes' wines, grew 20\% in volume." Pam Strayer, "The Organic Opportunity: will the US wine industry miss out," Wines and Vines, January 2017, www.winesandvines.com/columns/section/26/article/178258/The-Organic-OpportunityWill-the-U.S.-Wine-Industry-Miss-Out <accessed on May 26, 2018>

5. On the changes brought by globalization in the world's wine markets, see Kym Anderson, ed, The World's Wine Markets: Globalization at work, Edward Elgar Publishing, 2005 and its update Kym Anderson and Vincent Pinilla, eds, Wine Globalization : A New Comparative History, CUP, 2018.

6. For a recent update on e-commerce growth in the wine market, see this article in The Spirits Business, www.thespiritsbusiness.com/2018/02/us-online-alcohol-sales-hit-1-7-billion/ <accessed on May 26, 2018>

7. See Liz Thach, Terry Lease and Marieska Barton, "Exploring the impact of social media practices on wine sales in US wineries," Journal of Direct, Data and Digital Marketing Practice Vol. 17 Issue 4 (June 2016): 272-283.

8. All the information taken from the survey can be found in this article: Liz Thach and Kathryn Chang, "Adventure, Tradition, and Semi-Sweet Wines Highlighted in 2016 American Wine Consumer Survey," Wine Business.com, 6 December 2016. www.winebusiness.com/news/? go=getArticle\&dataid=177492 <accessed on March 1, 2018>

9. L. Lockshin and J. Hall, "Consumer purchasing behaviour for wine: what we know and where we are going," University of South Australia, Wine Marketing Research Group (2003): 2.

10. Jancis Robinson, The Oxford Companion to Wine, Third Edition, (Oxford: Oxford University Press, 2006), 102.

11. J. C. Olson and J. Jacoby, "Cue Utilization in the Quality Perception Process," SV - Proceedings of the Third Annual Conference of the Association for Consumer Research, eds. M. Venkatesan (1972): 167-179.

12. Lockshin, "Consumer purchasing behaviour for wine: what we know and where we are going," 2.

13. D. Jennings and C. Wood, "Wine: Achieving competitive advantage through design," International Journal of Wine Marketing, vol. 6 (1) (1994): 49-61.

14. S. Mueller and G. Szolnoki, "The relative influence of packaging, labelling, branding and sensory attributes on liking and purchase intent: Consumers differ in their responsiveness." Food Quality and Preference, 21(7) (2010): 774-783.

15. C.A Boudreaux and S. Palmer, "A charming little cabernet: effects of wine label design on purchase intent and brand personality," International Journal of Wine business Research 19 (2007): 170-186.

16. All figures taken from the Wine Institute.

17. These categories are the ones used by most wine marketing studies available concerning the US market. Although these may be questioned today, I decided to keep them in this article so as to be able to use the data available; see Inkje Hoestra, Conrad Lashley and Elena Cavagnaro, "Generation Y's Attitude Towards Organic Wine," Research in Hospitality Management 5 (1), (2015): 107-113. 
18. W. Lyons, “Who's driving world wine consumption?" Wall Street Journal online, 28 January 2015.

19. "Wine Opinions. American Wine Generations report," Wine Business Blog, 24 March 2016 https://www.winebusiness.com/blog/?go=getBlogEntry\&dataId=166661<accessed March 1 2018> 20. Larry Lockshin and Armando Corsi, "Consumer behaviour for wine 2.0: A review since 2003 and future directions," Wine Economics and Policy Vol 1 Issue 1, (December 2012): 2-23.

21. “2015 California Wine Sales in U.S. Hit \$31.9 Billion Retail Value," Wine Institute, 8 July 2016 https://www.wineinstitute.org/resources/pressroom/07082016 <accessed March 1 2018>

22. See Yves Jeanneret, Emmanuël Souchier. "L'étiquette des vins: analyse d'un objet ordinaire." Communication et langages $n^{\circ} 121$, (1999): 72-85.

23. For more information on the influence of back label see Lockshin and Mueller 2010.

24. This system, started in the early 1980s, is a rough equivalent of the French Appellation Contrôlée.

25. See Jancis Robinson, The Oxford Companion to Wine, 385-386

26. For more information on the subject see Philippe Margot, L'Art et le Vin: Les œuvres originales de grands artistes contemporains pour Château Mouton Rothschild (Editions Cepdivin, 2009)

27. Steven Charters, Wine and Society, 199.

28. Steven Charters, Wine and Society, 199.

29. Jancis Robinson, The Oxford Companion to Wine, 719.

30. Ted Loosdec, "Lots of Wine, but None to Drink," New York Times, 05 December 2010.

31. Paul Franson, "Labels Gone Wild," Wine Enthusiast, 1 March 2016.

32. Liz Thach and Kathryn Chang, "Adventure, Tradition, and Semi-Sweet Wines Highlighted in 2016 American Wine Consumer Survey."

33. Fredric Jameson, Postmodernism, or, the Cultural Logic of Late Capitalism, (Durham: Duke UP, 1991) $\mathrm{x}$.

34. Fredric Jameson, Postmodernism, or, the Cultural Logic of Late Capitalism, 2.

35. Mike Featherstone, Consumer Culture and Postmodernism, (London: Sage, 1991) 15, quoting first F. Jameson in "Postmodernism: Or the Cultural Logic of Late Capitalism," New Left Review (1984): 146 and then in "Postmodernism and the Consumer Society," in H. Foster, ed, Postmodern Culture, (London: Pluto Press, 1984)

36. Steven Charters, Wine and Society, 202 quoting from A. Tomlinson, "Introduction," in A. Tomlinson, ed, Consumption, Identity and Style, (London: Routledge, 1990), 1-30.

37. Steven Charters, Wine and Society, 203.

38. See Steven Charters, Wine and Society, 141, for wine market segmentation research studies and the different types of consumers.

39. Turner Classic movies wine club. http://tcmwineclub.com/ <accessed March 1 2018>

40. Steven Charters, Wine and Society, 200.

41. For more information on rocknroll in American culture see for instance: Charlie Gillett, The Sound of the City: The Rise of Rock and Roll, (New York: Pantheon, 1984); George Lipsitz, Time Passages: Collective Memory and American Popular Culture, (Minneapolis: University of Minnesota Press, 1990); Theo Cateforis ed., The Rock History Reader, 2d ed., (New York: Routledge, 2013).

42. Rocknroll wine. http://www.rocknrollwine.com <accessed March 1 2018>

43. Rocknroll wine. http://www.rocknrollwine.com <accessed March 1 2018>

44. Wines that rock. http://www.winesthatrock.com <accessed March 1 2018>

45. Wines that rock. http://www.winesthatrock.com <accessed March 1 2018>

46. Wines that rock. http://www.winesthatrock.com <accessed March $12018>$

47. Wines that rock. http://www.winesthatrock.com <accessed March 1 2018>

48. Salmonsafe. https://salmonsafe.org/ <accessed March 1 2018>

49. For more on greenwashing, see Gareth Morgan and Richard Tresidder, Contemporary Wine Studies. Dancing with Bacchus (New York: Routledge, 2016): 163-165. 
50. Michael B. Beverland, "Crafting Brand Authenticity: the Case of Luxury Wines," Journal of Management Studies 42:5, (July 2005), 1008.

51. Steven Charters, Wine and Society, 200.

52. In the US: Bedrock Wine co., Marietta Cellars, Boggle Vineyards, Brigadoon are just a few examples. In France, see the 2016 Bordeaux wines campaign for instance https://pro.planetebordeaux.fr/news-pro/campagne-publicitaire-nouvelle-dynamique, Monbazillac wine "Nos Racines" by Famille Raymond, in Sicily the wines by Salvo Foti, I Vigneri, use the image of a vine as a logo and quality and terroir marker for specific wines made in the Etna area. These are but a few of the hundreds of examples that can be found.

53. Jancis Robinson, The Oxford Companion to Wine, 693.

54. Jancis Robinson, The Oxford Companion to Wine, 693.

55. See Bonterra website http://www.bonterra.com/ <accessed March 1, 2018> and more info on http://www.multivu.com/players/English/7990251-bonterra-vineyards-30-years-organic-

farming/ <accessed March 1, 2018>

56. See the old American labels shown on the page of Thomas Pinney, A History of Wine in America: From the Beginnings to Prohibition, (Berkeley: University of California Press, 1989), http://ark.cdlib.org/ark:/13030/ft967nb63q/ <accessed on May 26, 2018>

57. See the YesMore agency page "Ten label design trends to have on your radar ", https:// yesmore.co.uk/label-design-trends/ <accessed on May 26, 2018>

\section{ABSTRACTS}

The US has been the world's largest wine market since 2010 and is the number one country for wine consumption. This general growth in production and consumption reflects a change in the US consumer base, with the rising importance of millennials. To attract all profiles of consumers and be visible, winemakers have to find the right label. It is my contention that the current trends in label designs in the US are oscillating between culture and nature. On the one hand, various trends in label designs are using American popular cultures, reflecting the culture of consumers, commodifying it and often erasing all traces of "classic" wine culture. On the other hand, there is a global development towards the promotion of a more "natural" and "authentic" product. This "back to nature" visual trend values the intrinsic qualities of the wine.

\section{INDEX}

Keywords: Wine, labels, United States, popular culture, marketing, authenticity, terroir

\section{AUTHOR}

\section{ELÉONORE OBIS}

Eléonore Obis is a fully-certified teacher of English at Paris-Sorbonne Universités. She holds a $\mathrm{PhD}$ in contemporary British drama and is also a wine enthusiast. She translated Patrick McGovern's seminal book Ancient Wine (2015) and wrote articles on wine tasting and wine culture, from the perspective of translation studies as well as linguistics. She completed the WSET level 3. 